Kansas State University Libraries

New Prairie Press

\title{
Editor's Preface and Table of Contents
}

Gary L. Gadbury

Follow this and additional works at: https://newprairiepress.org/agstatconference

Part of the Agriculture Commons, and the Applied Statistics Commons

\section{c) (i) $\Theta \Theta$}

This work is licensed under a Creative Commons Attribution-Noncommercial-No Derivative Works 4.0 License.

\section{Recommended Citation}

Gadbury, Gary L. (2009). "Editor's Preface and Table of Contents," Conference on Applied Statistics in Agriculture. https://doi.org/10.4148/2475-7772.1072

This is brought to you for free and open access by the Conferences at New Prairie Press. It has been accepted for inclusion in Conference on Applied Statistics in Agriculture by an authorized administrator of New Prairie Press. For more information, please contact cads@k-state.edu. 


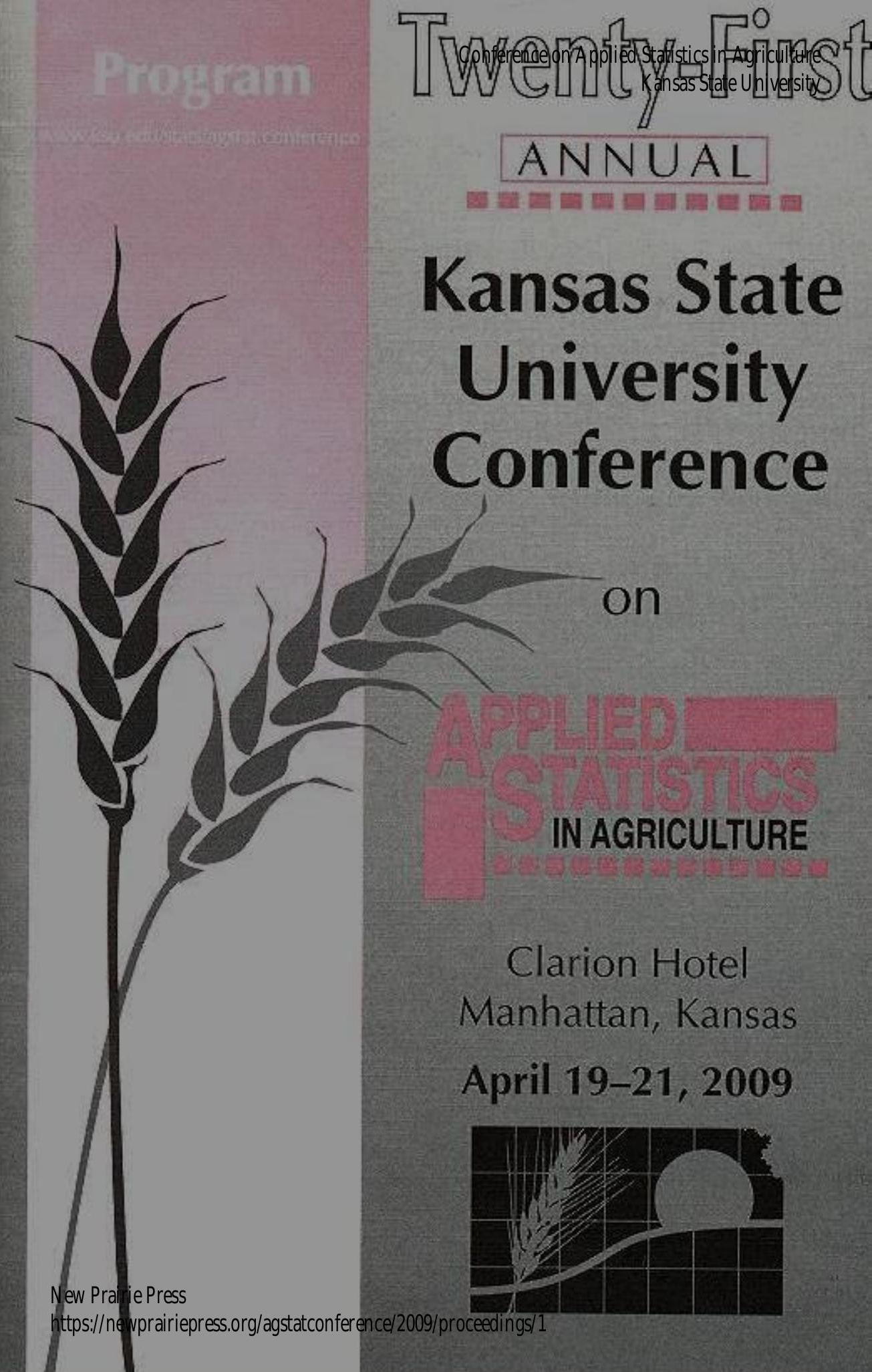




\section{Preface}

These proceedings contain papers presented in the twenty-first annual Kansas State University Conference on Applied Statistics in Agriculture, held in Manhattan, Kansas, April 19 - April 21, 2009. The purpose of the conference is to provide a forum for discussion on the application of statistics to problems in agricultural sciences. Papers and posters presented at the conference and included in the proceedings are intended to provide information to both the statistician and agricultural researcher on current issues of agricultural and general statistical interest. More than one hundred registrants for this year's conference came from across the country and represented government, industry, and academia.

The keynote speakers were George Milliken and Dallas Johnson, emeriti faculty from Kansas State University. Dr's. Milliken and Johnson presented a workshop on April 19 titled "Analysis of Messy Data Revisions" that included updates from their recently published second edition of volume I, Designed Experiments.

Each contributed paper was refereed before being accepted for publication in these proceedings. The papers were accepted for publication based on their interest, relevance, innovation and application to the agricultural sciences and statistics.

Sincere thanks to the following individuals: Philip Dixon, Adam Pintar, Debbie Boykin, Matt Kramer, Bill Price, Kathy Yeater, Leigh Murray, Edzard Van Santen, John Stevens, Jixiang Wu, Brent Burch, Qinfang Xiang, John Keighley, V.A. Samaranayake, Haiyan Wang, John Boyer, and Jim Higgins for referring submitted manuscripts, Pam Schierer and student volunteers for help in conference planning and organization, and Julie Dillingham for managing the reviewing process and for assembling the proceedings. Special thanks go to our conference sponsors for their continued support: American Statistical Association, Eli Lilly \& Company, Pfizer Inc, Pioneer Hi Bred-a Dupont Business and the USDA-ARS.

Gary L. Gadbury

2009 Proceedings Editor 


\section{Table of Contents}

Associating SNPS With Binary Traits

Alexander E. Lipka, Purdue University

George P. McCabe, Purdue University

R.W. Doerge, Purdue University

Bayesian Nonparametric Biosassay Estimation

Bahman Shafii, University of Idaho

William J. Price, University of Idaho

Relative Potency Estimation in Direct Bioassay with Measurement Errors

Weixing Song, Kansas State University

Hierarchical Bayesian Methods to Model Heterogeneity in Cow-and HerdLevel Relationships between Milk Production and Reproduction in Dairy Cows

Nora M. Bello, Michigan State University

Juan P. Steibel, Dept. of Fisheries and Wildlife, Michigan State University

Robert J. Tempelman, Michigan State University

Statistical Issues in Next-Generation Sequencing

69

Paul L. Auer, Purdue University

R.W. Doerge, Purdue University

Comparative Study of Time Series and Multiple Regression for Modeling Dependence of Cattle Body Temperature on Environmental

Variables During Heat Stress

M. Pathak, University of Nebraska

A.M. Parkhurst, University of Nebraska

R.A. Arias, University of Nebraska

T.L. Mader, University of Nebraska

Application of the DYA Method to Compare Wheat Cultivar Yields

Arlin Feyerherm, Kansas State University

Allan Fritz, Kansas State University

Statistical Methods for Affymetrix Tiling Array Data

Gayla R. Olbricht, Purdue University

Nagesh Sardesai, Purdue University

Stanton B. Gelvin, Purdue University

Bruce A. Craig, Purdue University,

R.W. Doerge, Purdue University 
Mapping QTL with Covariates

126

Cherie A. Ochsenfeld, Purdue University

Kristofer Jennings, Purdue University

R.W. Doerge, Purdue University

A Stem Profile Model Calibrated by Nonlinear Mixed-Effects Modeling

Yuqing Yang, Alberta Dept. of Sustainable Resource Development, Canada

Shongming Huang, Alberta Dept. of Sustainable Res. Development, Canada

Shawn X. Meng, Alberta Dept. of Sustainable Resource Development, Canada

Sequential Bayesian Classification: DNA Barcodes

Michael P. Anderson, Kansas State University

Suzanne Dubnicka, Kansas State University

Using Time Series to Study Dynamics of Sweat Rates of Holstein Cows

Exposed to Initial and Prolonged Solar Heat Stress

B. Liang, University of Nebraska

A.M. Parkhurst, University of Nebraska

K.G. Gebremedhin, Cornell University

C.N. Lee, University of Hawaii

R.J. Collier, University of Arizona

P.E. Hillman, Cornell University

Comparing Experimental Designs for a Bi-Logistical Model Used to Estimate Heat Stress When Moving Feedlot Cattle

$X$. Li, University of Nebraska

A.M. Parkhurst, University of Nebraska

T.L. Mader, University of Nebraska

Using Time Series To Study Effect of Air Temperature on Body

Temperature of Cows in Puerto Rico

198

$Y$. Zeng, University of Nebraska

A.M. Parkhurst, University of Nebraska

J. Pantoja, University of Puerto Rico

Proc Report in Style

Wendy Boberg, Arkansas Foundation for Medical Care, Arkansas

2009 List of Attendees 
Achberger, Tilman-Purdue University`

Anderson, Steven- Anderson Research, LLC

Aref, Susanne- Aref Consulting Group, LLC

Bahman, Shafii-University of Idaho

Bargen, Jason-AgSpan

Baumann, Douglas-Purdue University

Bello, Nora-Michigan State University

Blankenship, Erin-University of Nebraska

Boberg, Wendy-AFMC

Boykin, Debbie-USDA/ARS

Brejda, John-University of Nebraska

Brennan, Meghan-University of Florida

Brewer, James

Camp, Mary-USDA/ARS

Cheng, Fu-Chih-North Dakota State University

Chernoff, William-Kansas State University

Cochrane, Chun-Yen-Kansas State University

Cui, Zhanglin-Eli Lilly \& Company

Dixon, Philip-lowa State University

Doerge, Rebecca-Purdue University

Durham, Susan-Utah State University

Fabellar, Anabella-Monsanto Company

Feng, Lizhi-Pioneer Hybrid International, Inc.

Fergen Brian-USDA, APHIS, VS, CVB

Feyerherm, Arlin-Kansas State University

Gbur, Edward-University of Arkansas

Green, Jennifer-University of Nebraska

Hagel, Emily-University of Nebraska

Hassen, Abebe-Pioneer Hybrid International, Inc

Heaton, Louis-USDA/ARS

Hinds, Mark-Pioneer Hi-Bred Int'I

Hong, Bonnie-Pioneer Hybrid International Inc.

Huang, Xuewen-Monsanto Company

Jiang, Dongming-Monsanto Company

Johnson, LuAnn-UND-GFHNRC

Jun, Hyoungjin-Kansas State University

Kadaru, Suresh - Syngenta Seeds, Inc.

Keating, Karen-Kansas State University

Kramer, Matt-USDA?ARS

Kratzer, Dal-ESCI

Kreider, Scott

Lamm, Freddie-NW Research-Extension Ctr.
Li, Xiaopeng-University of Nebraska

Liang, Bixia-University of Nebraska

Library, Albert Mann

Lipka, Alexander

Liu, Jia-lowa State University

Livermore Auer, Paul-Purdue University

Luo, Lang

Mackey, Bruce-USDA/ARS

MacKinnon, April-Milliken Associates, Inc.

Malladi, Sukhaswami-Hills Pet Nutrition, Inc.

Meek, David-USDA/ARS

Murray, Leigh-Kansas State University

Ochsenfeld, Cherie-Purdue University

Olbricht, Gayla-Purdue University

Ou, Zhining-Kansas State University

Page, Garritt-lowa State University

Palmquist, Debra-USDA/ARS

Parkhurst, Anne-University of Nebraska

Pathak, Manoj-University of Nebraska

Peng, Liang-Kansas State University

Perera, Muditha-Kansas State University

Phillips, Gregory-USDA, NWRC

Pintar, Adam-lowa State University

Price, Bill-University of Idaho

Ramirez, Girly-Kansas State University

Ridpath, Harold-Ctr. For Veterinary Biologics

Rogers, Paul

Samarakoon, Nishantha-Kansas State University

Scherer, Peter-Dow AgroSciences

Senne, Lane

Smith, David-New Mexico State University

Song, Tingting-Kansas State University

St. Pierre, Normand-Ohio State University

Staudhammer, Christina-University of Florida

Stevens, John-Utah State University

Stroup, Walt-University of Nebraska

Thompson, Kevin-University of Arkansas

Tolos, Siti-Kansas State University

Trapp, Alln-lowa State University

Vahl, Christopher-North Dakota State University

Van Santen, Edsard-Auburn University

VanDyke, Rhonda-University of Cincinnati 
Vinyard, Bryan-USDA/ARS

Wang, Dong-University of Nebraska

Whitehand, Linda-Western Regional Res. Ctr.

Wu, Jixiang-Mississippi State University

Xie, Lin

Yankovskyy, Yevhen-University of Kansas

Yates, Heath-Kansas State University

Yeater, Kathy-USDA/ARS

Yu, Jianming-Kansas State University

Yum, Man Yu-lowa State University

Zeng, Yan-University of Nebraska

Zeng, Beiyan-Monsanto Company

Zhu, Chengsong-Kansas State University

Zoh, Roger- lowa State University 


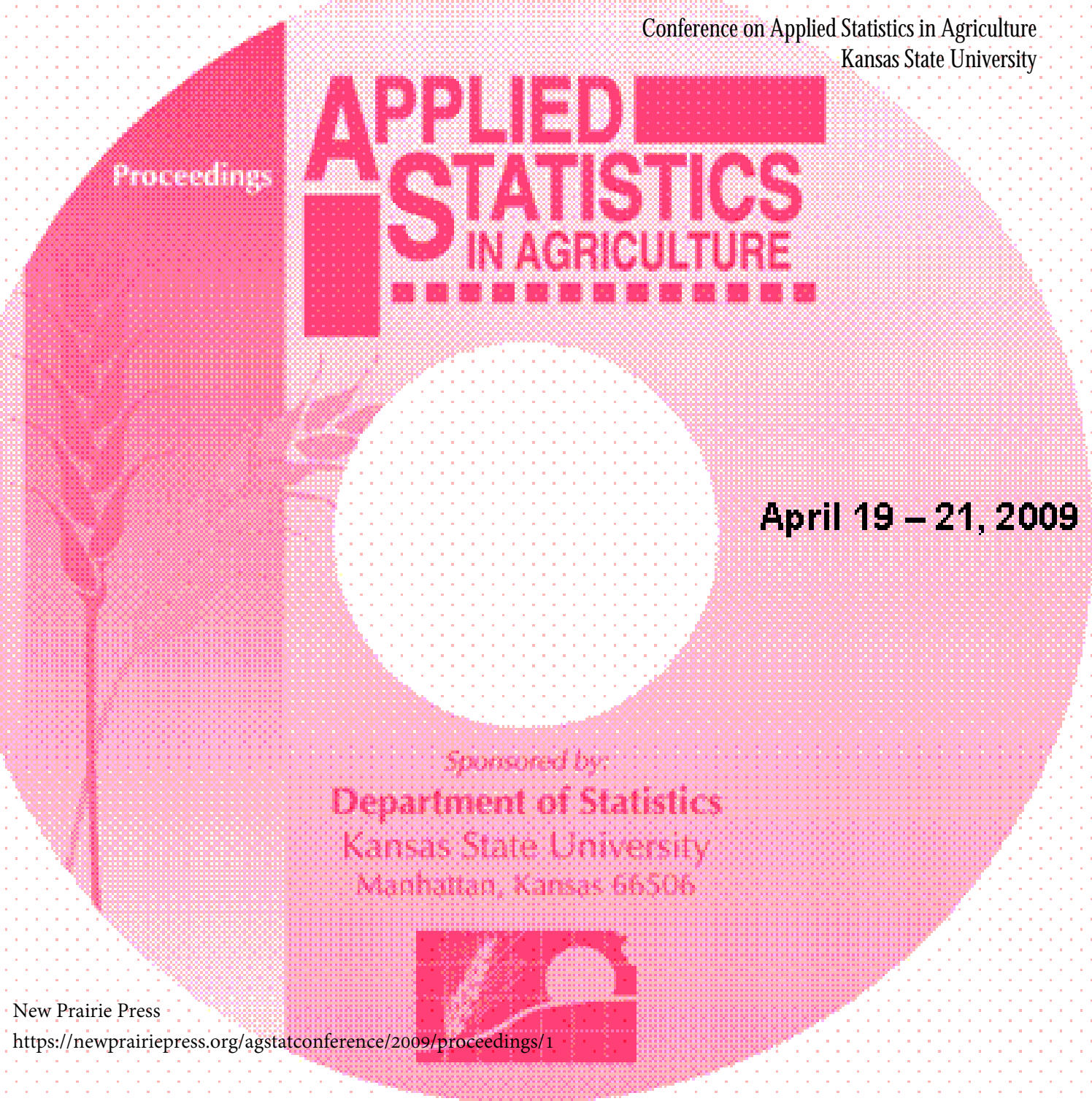

